\title{
Carotenoids and Phenols of Organically and Conventionally Cultivated Potato Varieties
}

\author{
I. Murniece, Z. Kruma, I. Skrabule, and A. Vaivode
}

\begin{abstract}
Many of the compounds present in potato are important because of their beneficial effects on health, therefore, are highly desirable in the human diet. The orange and yellow colour of the tuber flesh is due to carotenoids. The aim of this research was to determine the content of total phenolic content and carotenoids in relationship with the colour of organically and conventionally cultivated potato varieties before and after period of storage. In the research 31 potato samples of 12 potato varieties were analyzed on total carotenoid, total phenolic content and colour. Obtained results show that there was significant influence on carotenoid content between different cultivation environments $(p<0.05)$ and between varieties $(p<0.05)$. Total phenolic content significantly varies both per variety $(p<0.001)$ and storage conditions $(p<0.001)$.
\end{abstract}

Index Terms-Potato variety, total phenol content, carotenoids, organic, conventional.

\section{INTRODUCTION}

Potato (Solanum tuberosum L.) is one of the most important food crops in the world following wheat and rice to provide essential nutrients, mainly carbohydrate [1]. The research in potato chemistry has established the fact that there is a lot more in potatoes than starch. Phytochemicals content in potatoes can be enhanced by developing new varieties from available germplasm high in these compounds. Natural colourant and antioxidant present in purple- and red-flesh potatoes can be used for developing functional foods/nutraceuticals. Considering the large quantities in which potatoes are consumed throughout the world, potatoes could be a very good vehicle for addressing some health related problems [2]. Many of the compounds present in potato are important because of their beneficial effects on health, therefore, are highly desirable in the human diet [3].

Colour is an important food quality parameter. It affects consumer acceptance [4] and can even evoke emotional feelings in humans [5]. Coloured potatoes have attracted the attention of investigators as well as consumers because of their antioxidant activities, taste and appearance [6]. The antioxidant activity in coloured potatoes is associated with the presence of polyphenols anthocyanins, flavonoids, carotenoids, ascorbic acid, tocopherols, alpha-lipoic acid and selenium [7]. Therefore, coloured potatoes have the potential to be one of the richest sources of antioxidants in the human

Manuscript received July 25, 2013; revised September 29, 2013.

Irisa Murniece and Zanda Kruma are with the Latvia University of Agriculture, Faculty of Food Technology, Jelgava, Latvia (tel.: 0037163005644; fax: 0037163022829, e-mail: irisa.murniece@1lu.lv, zanda.kruma@1lu.1v).

Ilze Skrabule and Aija Vaivode are with the State Plant Breeding Institute, Priekuli, Latvia (e-mail: skrabuleilze@gmail.com ). diet.

As food and life style choices have been increasingly recognised as useful approaches in prevention or delaying the onset of chronic diseases, more and more research and commercial development are focused on food phytochemicals such as polyphenolics and carotenoids [8]-[14]. In addition to supplying energy, potatoes contain a number of health promoting phytonutrients such as phenolics, flavonoids, folates, kukoamines, anthocyanins, and carotenoids [15] particularly the pigmented or coloured varieties [16]-[19].

Carotenoids are lipophilic compounds synthesized in plastids from isoprenoids [20] which are widespread in nature and have broad range of functions, especially in relation to human health and their role as biological antioxidants [20], [21]. Because of their high carotenoids content potatoes are particularly beneficial for eye health [22], [23]. Lutein, zeaxanthin, violaxanthin and neoxanthin are the major carotenoids present in potatoes and $\beta$-carotene is present in trace amounts [24].

Potato cultivars with white flesh contained less carotenoids as compared to cultivars with yellow or orange flesh. Total carotenoids content was reported in the range of 50-350 $\mu \mathrm{g} / 100$ FW and 800-2000 $\mu \mathrm{g} 100 \mathrm{~g}^{-1} \mathrm{FW}$, respectively, in white- and yellow-fleshed potato cultivars [24].

Polyphenols comprise over 8000 identified substances, which can be divided into groups according to their chemical structure, such as phenolic acids, stilbenes, coumarins, lignins and flavonoids [15].

Phenolic compounds are considered to be health-promoting phytochemicals as they have shown in vitro antioxidant activity and have been reported to exhibit beneficial antibacterial, antiglycemic, antiviral, anticarcinogenic, anti-inflammatory and vasodilatory properties [25], [26]. Polyphenols are recognized as the most abundant antioxidants in our diet [27]. Potatoes are a good source of these compounds. Phenolic compounds represent a large group of minor chemical constituents in potatoes, which play an important role in determining their organoleptic properties. Further, phenolics have a wide-array of health providing characteristics [28], therefore, have potential for use as functional food for improving human health. The phenolic content of potatoes was reported to be high, and ranged from 530 to $1770 \mu \mathrm{g} \mathrm{g}^{-1}$ [29]. Potatoes were considered the third most important source of phenols after apples and oranges [30]. Talburt et al. reported presence of lignin, coumarins, anthocyanins and flavones, tannins, monohydric phenols and polyhydric phenols in potatoes [31].

Potato quality varies depending on the growing area, cultivar [32] and aspects of the chemical composition of main 
crop potato tubers have been shown to depend on the cultivation system as well. The improved qualitative value of organic vs. conventional produce, however, has not been ascertained [33], [34]. Although nutrient content depends on a number of factors, the potato variety is thought to be among the most significant factors [35].

Potato production has high environmental costs. In fact, it requires high inputs of water, fertilisers and pesticides that can cause soil degradation and pollution. In the last years, the demand for high quality foods and the government policies focused on environmentally sustainable agricultural systems have stimulated a rapid expansion of new farming methods. Studies comparing the productivity of organic practices to conventional agriculture provide an excellent example of the wide range of benefits that may result from a conversion to sustainable agricultural methods. Both organic and low-input systems increase the organic carbon content of the soil and the pools of stored nutrients, each of which are critical for long-term fertility maintenance [36]-[38].

In 2008, the most important arable crop in the EU27 was cereals (44\% of the fully converted organic area under arable crops), followed by green fodder (42\%), other arable crops such as dried pulses, potatoes, sugar beet, arable seeds and seedlings (7\%), fresh vegetables and industrial crops (both 4\%) [39]. As a result the interest in organic agriculture and environmentally-friendly agricultural products is increasing, and in particular consumers have made potatoes one of their top organic purchases among fresh vegetables even though organic potatoes carry a price significantly higher than most other vegetables [40].

In this respect, it is not known whether and how different agriculture techniques and/or cultivation systems may affect the nutrients composition of the final product. Comparison of organic and conventional foods in terms of nutritional value, sensorial quality and food safety, has often highlighted controversial results. As a consequence, a clear link between cultivation system and nutritional profile of agricultural products is still missing [41]-[42].

The aim of this research was to determine the content of total phenolic content and carotenoids in relationship with the colour of organically and conventionally cultivated potato varieties before and after period of storage.

\section{MATERIALS AND MethodS}

\section{A. Soil and Climate}

The potatoes were planted in the middle of May and harvested in last decades of August or first days of September Field trials were conducted in three replications. The certified potato seed material was used. Seed tubers were planted in rows, the distance between rows was $0.7 \mathrm{~m}$ and the distance between tubers $0.3 \mathrm{~m}$.

Organic field. The soil type was sod podzolic (PVv), loamy sand. Organic matter content in soil was $25 \mathrm{mg} \mathrm{kg}^{-1}$, $\mathrm{pH}_{\mathrm{KCl}}$ was 6.3 , the availability in soil of $\mathrm{K}$ was low and $\mathrm{P}$ was medium. The common agronomic practices were used during vegetation period.

Conventional field. The soil type in conventional field was sod-podzolic (PVv), sandy loam. Organic matter content in soil was $27 \mathrm{mg} \mathrm{kg}^{-1}$, pHKCl was 5.7, availability of $K$ and $P$ in soil was high. Fertilizer $P-55, K-90 \mathrm{~kg} \mathrm{ha}^{-1}$ was used in conventional field, two rates of $\mathrm{N}$ fertilizer was used $N 1-60$ $\mathrm{kg} \mathrm{ha}^{-1}$ and $N 2-120 \mathrm{~kg} \mathrm{ha}^{-1}$. The common agronomic practices were used during vegetation period. Herbicides in field were used for weed control. The fungicides for restriction fungal diseases were used two times in July.

Weather conditions. The weather conditions were warmer than perennial data (PD) with heavily rainfalls occasionally during growing period 2011. The average air temperature in beginning of growing period (end of May and first part of June) exceeded PD for $0.6{ }^{\circ} \mathrm{C}$. The weather was hot and dry in rest of June, and the precipitation reached only $46 \%$ of PD. During July, the air temperature was similar to the PD. Weather in July was dry (precipitation only $85 \%$ of PD), but rainfalls exceeded the PD by $109 \%$ in the second decade of August. The infection of late blight started in mid-August when the tubers were mostly developed.

The haulm was cut in last decade of August and the tubers were harvested in the beginning of September.

Potatoes were stored at the State Priekuli Plant Breeding Institute at an air temperature of $4{ }^{\circ} \mathrm{C}$ and at a relative air humidity of $80 \pm 5 \%$.

\section{B. Tubers}

In the experiment twelve potato (Solanum tuberosum L.) varieties with white, yellow and violet coloured flesh were evaluated, whose seed was obtained in the State Priekuli Plant Breeding Institute (SPPBI) (Latvia) and from abroad (. In cooperation with the SPPBI potatoes were grown in organic and conventional field in 2011. The characterization of potato varieties is present in Table I.

\section{Sample Handling}

For each testing period, a total of $10 \mathrm{~kg}$ (around 50-60 potato tubers) of table potato tubers per variety were selected into small piles, from ten different wooden boxes (size of the box: $90 \mathrm{~cm}(\mathrm{l}) \times 50 \mathrm{~cm} \mathrm{(w)} \times 40 \mathrm{~cm}(\mathrm{~h}))$. Five potatoes were selected from several location points of each box. Afterwards, the selected potato sub-piles were mixed together into one final pile and then divided into three batches. Potatoes from each batch were then mixed, homogenized and used for analyses [43]. All operations during sample preparation were performed very quickly so as to avoid deviations from the qualitatively obtained results. In the analysis on TPC, carotenoids and DM, the test and analysis was run in triplicate and averaged.

\section{Dry Matter, Carotenoid and Total Phenol Content}

Dry matter (DM) content of potato tubers was determined by ISO 6496:1999 [44]. Carotenoids were analyzed by spectrophotometric method (with the UV/VIS spectrophotometer Jenway 6705) at $440 \mathrm{~nm}$ [45].

For extraction of phenolic compounds five grams of the homogenized sample were extracted with $50 \mathrm{ml}$ of ethanolwater solution $(80 \%)$ in a conical flask with a magnetic stirrer (magnet $4.0 \times 0.5 \mathrm{~cm}$ ) at $700 \mathrm{rpm}$ for $1 \mathrm{~h}$ at room temperature $\left(20 \pm 1{ }^{\circ} \mathrm{C}\right)$. The potatoes extracts were then filtered via the paper with No 89. 
TABLE I: DESCRIPTION OF POTATO VARIETIES

\begin{tabular}{|c|c|c|c|c|}
\hline Variety & $\begin{array}{c}\text { Shape of } \\
\text { tubers }\end{array}$ & Colour of skin and flesh & Maturity & Additional information \\
\hline Agrie dzeltenie & oval round & skin - russet yellow; flesh - yellow & early & bred at SPPBI* \\
\hline Prelma & oval & skin - yellow; flesh - yellow & mid-early & bred at SPPBI \\
\hline Imanta & long oval & Skin - yellow with pink eyes; flesh - white & mid-late & bred at SPPBI \\
\hline Lenora & round oval & skin - yellow; flesh - yellow & mid-early & bred at SPPBI. \\
\hline Brasla & round & skin - yellow; flesh - yellow & mid-late & bred at SPPBI \\
\hline Bionica & round oval & skin - light yellow; flesh - white & mid-early & bred at C. Meyer B.V., the Nederlands \\
\hline Annuscha & round oval & skin - yellow; flesh - yellow & early & bred at Europlant, Germany \\
\hline Blue Congo & long oval & skin - violet; flesh - violet & mid-late & the Czech Republic Gene bank \\
\hline Gundega & oval & skin - light red pink; flesh - yellow & mid-late & bred at SPPBI \\
\hline S04009-37 & oval & skin - violet; flesh - white & mid-late & SPPBI breeding material \\
\hline S03135-10 & round & skin - light pink with pink eyes; flesh - light yellow & early & SPPBI breeding material \\
\hline S99108-8 & round oval & skin - light yellow with pink eyes; flesh - yellow & mid-early & SPPBI breeding material \\
\hline
\end{tabular}

* SPPBI- state priekuli plant breeding institute

TABLE II: DRy MATTER CONTENT IN TUBERS OF POTATO VARIETIES AFTER HARVESTING AND AFTER STORAGE, \%

\begin{tabular}{|c|c|c|c|c|c|c|}
\hline \multirow{2}{*}{ Potato variety } & \multicolumn{3}{|c|}{ Before storage } & \multicolumn{3}{|c|}{ After storage } \\
\hline & Organic & Conventional $N 1^{*}$ & Conventional $N 2 * *$ & Organic & Conventional $N 1^{*}$ & Conventional $N 2 * *$ \\
\hline $\begin{array}{l}\text { Agrie } \\
\text { dzeltenie }\end{array}$ & $\begin{array}{c}18.30 \pm 0.1 \\
3\end{array}$ & $18.04 \pm 0.07$ & $17.50 \pm 0.08$ & $\begin{array}{c}19.56 \pm 0.2 \\
1\end{array}$ & $19.52 \pm 0.10$ & $18.36 \pm 0.06$ \\
\hline Prelma & $\begin{array}{c}19.10 \pm 0.0 \\
9\end{array}$ & $21.56 \pm 0.09$ & $19.50 \pm 0.07$ & $\begin{array}{c}19.84 \pm 0.0 \\
7\end{array}$ & $22.37 \pm 0.22$ & $19.33 \pm 0.16$ \\
\hline Imanta & $\begin{array}{c}25.87 \pm 0.0 \\
8\end{array}$ & $24.00 \pm 0.11$ & $23.10 \pm 0.22$ & $\begin{array}{c}26.73 \pm 0.2 \\
3\end{array}$ & $24.76 \pm 0.09$ & $24.42 \pm 0.19$ \\
\hline Lenora & $\begin{array}{c}22.55 \pm 0.1 \\
4\end{array}$ & $23.84 \pm 0.18$ & $22.80 \pm 0.27$ & $\begin{array}{c}23.75 \pm 0.1 \\
4\end{array}$ & $25.43 \pm 0.31$ & $24.51 \pm 0.32$ \\
\hline Brasla & $\begin{array}{c}24.35 \pm 0.1 \\
1\end{array}$ & $26.10 \pm 0.29$ & $25.90 \pm 0.10$ & $\begin{array}{c}25.41 \pm 0.1 \\
2\end{array}$ & $28.20 \pm 0.27$ & $27.66 \pm 0.07$ \\
\hline Bionica & $\begin{array}{c}20.80 \pm 0.2 \\
1\end{array}$ & $21.05 \pm 0.13$ & $18.80 \pm 0.20$ & $\begin{array}{c}22.18 \pm 0.1 \\
1\end{array}$ & $21.87 \pm 0.06$ & $20.56 \pm 0.05$ \\
\hline Annuscha & $\begin{array}{c}18.80 \pm 0.0 \\
8\end{array}$ & $19.50 \pm 0.11$ & $19.03 \pm 0.06$ & $\begin{array}{c}19.82 \pm 0.0 \\
6\end{array}$ & $20.32 \pm 0.15$ & $19.54 \pm 0.16$ \\
\hline Blue Congo & n.a. & $20.10 \pm 0.23$ & $18.60 \pm 0.10$ & n.a & $20.04 \pm 0.14$ & $20.04 \pm 0.19$ \\
\hline Gundega & n.a. & $23.10 \pm 0.17$ & $23.10 \pm 0.20$ & n.a. & $23.82 \pm 0.22$ & $22.89 \pm 0.09$ \\
\hline S04009-37 & n.a. & $25.60 \pm 0.21$ & $24.10 \pm 0.09$ & n.a. & $25.84 \pm 0.28$ & $25.33 \pm 0.19$ \\
\hline S03135-10 & n.a. & $19.80 \pm 0.14$ & $19.20 \pm 0.19$ & n.a. & $20.75 \pm 0.09$ & $19.89 \pm 0.28$ \\
\hline S99108-8 & n.a. & $19.55 \pm 0.06$ & $19.28 \pm 0.13$ & n.a. & $20.35 \pm 0.10$ & $19.26 \pm 0.30$ \\
\hline
\end{tabular}

N fertilizer: $* N 1-60 \mathrm{~kg} \mathrm{ha}^{-1}$ and $* * N 2-120 \mathrm{~kg} \mathrm{ha}^{-1}$

Each value is expressed as the mean \pm standard deviation $(n=9)$.

\begin{tabular}{|c|c|c|c|c|c|c|}
\hline \multirow{2}{*}{$\begin{array}{l}\text { Potato } \\
\text { variety }\end{array}$} & \multicolumn{3}{|c|}{ Before storage } & \multicolumn{3}{|c|}{ After storage } \\
\hline & Organic & Conventional $N 1 *$ & Conventional $N 2 * *$ & Organic & Conventional $N 1 *$ & Conventional $N 2 * *$ \\
\hline $\begin{array}{l}\text { Agrie } \\
\text { dzeltenie }\end{array}$ & $\begin{array}{c}29.906 \pm 0.16 \\
2\end{array}$ & $27.925 \pm 0.066$ & $27.104 \pm 0.379$ & $\begin{array}{c}40.561 \pm 0.17 \\
9\end{array}$ & $34.560 \pm 0.098$ & $33.494 \pm 0.169$ \\
\hline Prelma & $\begin{array}{c}27.368 \pm 0.24 \\
7\end{array}$ & $22.911 \pm 0.062$ & $25.439 \pm 0.027$ & $\begin{array}{c}29.365 \pm 0.12 \\
4\end{array}$ & $27.012 \pm 0.166$ & $28.247 \pm 0.128$ \\
\hline Imanta & $\begin{array}{c}21.250 \pm 0.09 \\
3\end{array}$ & $16.001 \pm 0.257$ & $16.498 \pm 0.114$ & $\begin{array}{c}17.527 \pm 0.22 \\
7\end{array}$ & $21.644 \pm 0.134$ & $19.300 \pm 0.220$ \\
\hline Lenora & $\begin{array}{c}24.630 \pm 0.08 \\
8\end{array}$ & $15.530 \pm 0.018$ & $23.384 \pm 0.267$ & $\begin{array}{c}25.324 \pm 0.19 \\
7\end{array}$ & $15.957 \pm 0.264$ & $27.157 \pm 0.129$ \\
\hline Brasla & $\begin{array}{c}13.393 \pm 0.00 \\
9\end{array}$ & $18.305 \pm 0.192$ & $13.937 \pm 0.092$ & $\begin{array}{c}21.516 \pm 0.13 \\
4\end{array}$ & $22.648 \pm 0.231$ & $22.062 \pm 0.195$ \\
\hline Bionica & $\begin{array}{c}18.463 \pm 0.25 \\
9\end{array}$ & $17.281 \pm 1.184$ & $19.818 \pm 0.063$ & $\begin{array}{c}18.086 \pm 0.20 \\
9\end{array}$ & $18.463 \pm 0.064$ & $19.635 \pm 0.232$ \\
\hline Annuscha & $\begin{array}{c}23.841 \pm 0.35 \\
3\end{array}$ & $22.077 \pm 0.510$ & $15.073 \pm 0.230$ & $\begin{array}{c}31.316 \pm 0.16 \\
9\end{array}$ & $26.042 \pm 0.268$ & $27.003 \pm 0.133$ \\
\hline S04009-37 & n.a. & $15.552 \pm 0.214$ & $22.879 \pm 0.081$ & n.a. & $19.873 \pm 0.146$ & $18.310 \pm 0.165$ \\
\hline S03135-10 & n.a. & $26.038 \pm 0.118$ & $24.974 \pm 0.669$ & n.a. & $24.428 \pm 0.101$ & $28.963 \pm 0.252$ \\
\hline S99108-8 & n.a. & $12.198 \pm 0.017$ & $12.915 \pm 0.064$ & n.a. & $12.702 \pm 0.131$ & $17.354 \pm 0.065$ \\
\hline
\end{tabular}

The TPC of the extracts was determined according to the Folin-Ciocalteu spectrophotometric method [46] with some modifications. To $0.5 \mathrm{ml}$ of extract $2.5 \mathrm{ml}$ of Folin-Ciocalteu reagent (diluted 10 times with water) and, after 3 minutes $2 \mathrm{ml}$ of sodium carbonate $\left(\mathrm{Na}_{2} \mathrm{CO}_{3}\right)\left(75 \mathrm{~g} \mathrm{~L}^{-1}\right)$ was added. The sample was mixed. The control sample contained all the reaction reagents except the extract. After 30 minutes of incubation at room temperature, the absorbance was measured at $765 \mathrm{~nm}$. Total phenols were expressed as gallic acid equivalents (GAE)/100 $\mathrm{g}$ fresh weight (FW) of potatoes.

\section{A. Colour Analysis}

The colour of potato samples was measured by "Color Tec-PCM" device (USA). For evaluation of the colour of potato samples, potato slices were cut shortly before measurement in order to avoid formation of melanin 
pigments in non-enzymatic browning reaction which can affect the accuracy of colour measurement. Potato samples were covered by a transparent PP film ("Forpus"), thickness of $25 \mu \mathrm{m}$, to avoid direct contact between the aperture of the measuring device and the product. The colour was measured at least in seven various locations of the sample in order to obtain higher accuracy after calculation of the mean value. For data analysis, "ColorSof QCW" software was used.

TABLE IV: CAROTENOID CONTENT IN TUBERS OF POTATO VARIETIES AFTER HARVESTING AND AFTER STORAGE, MG $100 \mathrm{G}^{-1}$ FW

\begin{tabular}{|c|c|c|c|c|c|c|}
\hline \multirow{2}{*}{ Potato variety } & \multicolumn{3}{|c|}{ Before storage } & \multicolumn{3}{|c|}{ After storage } \\
\hline & Organic & Conventional $N 1 *$ & Conventional $N 2 * *$ & Organic & Conventional $N 1 *$ & Conventional $N 2 * *$ \\
\hline $\begin{array}{l}\text { Agrie } \\
\text { dzeltenie }\end{array}$ & $\begin{array}{c}0.211 \pm 0.01 \\
2\end{array}$ & $0.260 \pm 0.003$ & $0.233 \pm 0.027$ & $\begin{array}{c}0.312 \pm 0.00 \\
2\end{array}$ & $0.217 \pm 0.002$ & $0.246 \pm 0.001$ \\
\hline Prelma & $\begin{array}{c}0.147 \pm 0.00 \\
1\end{array}$ & $0.136 \pm 0.017$ & $0.104 \pm 0.008$ & $\begin{array}{c}0.121 \pm 0.00 \\
3\end{array}$ & $0.148 \pm 0.001$ & $0.148 \pm 0.001$ \\
\hline Imanta & $\begin{array}{c}0.043 \pm 0.00 \\
2\end{array}$ & $0.038 \pm 0.002$ & $0.043 \pm 0.003$ & $\begin{array}{c}0.031 \pm 0.00 \\
1\end{array}$ & $0.039 \pm 0.002$ & $0.029 \pm 0.002$ \\
\hline Lenora & $\begin{array}{c}0.318 \pm 0.00 \\
1\end{array}$ & $0.288 \pm 0.003$ & $0.318 \pm 0.005$ & $\begin{array}{c}0.308 \pm 0.00 \\
2\end{array}$ & $0.185 \pm 0.001$ & $0.282 \pm 0.002$ \\
\hline Brasla & $\begin{array}{c}0.233 \pm 0.00 \\
1\end{array}$ & $0.204 \pm 0.008$ & $0.178 \pm 0.006$ & $\begin{array}{c}0.143 \pm 0.00 \\
3\end{array}$ & $0.135 \pm 0.001$ & $0.100 \pm 0.001$ \\
\hline Bionica & $\begin{array}{c}0.227 \pm 0.00 \\
3\end{array}$ & $0.039 \pm 0.003$ & $0.073 \pm 0.007$ & $\begin{array}{c}0.036 \pm 0.00 \\
2\end{array}$ & $0.039 \pm 0.002$ & $0.024 \pm 0.001$ \\
\hline Annuscha & $\begin{array}{c}0.354 \pm 0.00 \\
3\end{array}$ & $0.227 \pm 0.004$ & $0.400 \pm 0.007$ & $\begin{array}{c}0.428 \pm 0.00 \\
2\end{array}$ & $0.333 \pm 0.004$ & $0.186 \pm 0.002$ \\
\hline Blue Congo & n.a. & $0.000 \pm 0.000$ & $0.073 \pm 0.000$ & n.a. & $0.015 \pm 0.001$ & $0.014 \pm 0.001$ \\
\hline Gundega & n.a. & $0.232 \pm 0.004$ & $0.124 \pm 0.001$ & n.a. & $0.105 \pm 0.001$ & $0.154 \pm 0.002$ \\
\hline S04009-37 & n.a. & $0.140 \pm 0.008$ & $0.165 \pm 0.005$ & n.a. & $0.129 \pm 0.002$ & $0.129 \pm 0.003$ \\
\hline S03135-10 & n.a. & $0.131 \pm 0.008$ & $0.058 \pm 0.003$ & n.a. & $0.165 \pm 0.005$ & $0.177 \pm 0.002$ \\
\hline S99108-8 & n.a. & $0.304 \pm 0.001$ & $0.306 \pm 0.003$ & n.a. & 0.2750 .004 & $0.354 \pm 0.002$ \\
\hline
\end{tabular}

$\mathrm{N}$ fertilizer: $* N 1-60 \mathrm{~kg} \mathrm{ha}^{-1}$ and $* * N 2-120 \mathrm{~kg} \mathrm{ha}^{-1}$

Each value is expressed as the mean \pm standard deviation $(n=9)$.

TABLE V: CORRELATION BETWEEN COLOUR (L*A*B*), CAROTENOIDS AND TPC

\begin{tabular}{|c|c|c|c|c|c|c|}
\hline \multirow{2}{*}{ Potato variety } & \multicolumn{3}{|c|}{ Carotenoids } & \multicolumn{3}{|c|}{ TPC } \\
\hline & Organic & Conventional $N 1 *$ & Conventional $N 2 * *$ & Organic & Conventional $N 1 *$ & Conventional $N 2 * *$ \\
\hline $\mathrm{L}^{*}$ & -0.58 & n.c. & n.c. & n.c. & -0.62 & n.c. \\
\hline$a^{*}$ & n.c. & -0.53 & n.c. & n.c. & 0.51 & n.c. \\
\hline $\mathrm{b}^{*}$ & 0.74 & 0.75 & 0.53 & 0.57 & n.c. & n.c. \\
\hline
\end{tabular}

$\mathrm{N}$ fertilizer: $* N 1-60 \mathrm{~kg} \mathrm{ha}^{-1}$ and $* * N 2-120 \mathrm{~kg} \mathrm{ha}^{-1}$

Each value is expressed as the mean \pm standard deviation $(n=9)$.

n.c. - no correlation was found.

\section{A. Statistical Analysis}

For statistical analysis, the data were processed using the S-PLUS 6.1 Professional Edition software. Data are presented as a mean \pm standard deviation (SD). The differences between independent groups were specified by two way analysis of variance (ANOVA), and values of $P<$ 0.05 were regarded as statistically significant. In case of establishing statistically significant differences, homogeneous groups were determined by Tukey's multiple comparison test at the level of confidence $\alpha=0.05$. Relationships between carotenoid, total phenolic content and dry matter were made by Principal Component Analysis (PCA).

\section{RESULTS AND DISCUSSION}

Dry matter (DM) content after a period of storage has increased in organically; conventionally $(N 1)$ and conventionally $(N 2)$ cultivated potatoes per $5.1 \%, 5.4 \%$ and $5.2 \%$, respectively. The highest loss in water content after a period of storage was found in the Bionica variety when cultivated conventionally (N2). In the very few potato tubers of the Prelma, Blue Congo, Gundega and S99108-8 varieties cultivated conventionally has been determined very small decrease in DM content after a period of storage (Table II).

The highest DM content before storage was found in the
Brasla variety when cultivated conventionally $(N 1)$ (i.e.

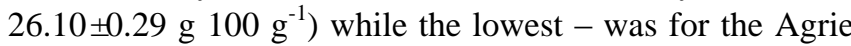
dzeltenie variety when cultivated conventionally $(N 2)$ (i.e.

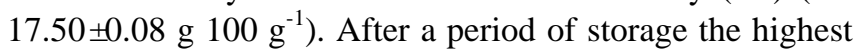
DM content was also found in the Brasla variety in the same growing conditions - conventionally $(N 1)$ (i.e. $28.20 \pm 0.20$ $\mathrm{g} 100 \mathrm{~g}^{-1}$ ) and the lowest, like in the case of the Brasla variety, it was in the Agrie dzeltenie variety cultivated conventionally

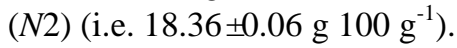

Comparing results of the same potato tubers of Brasla, Imanta and Lenora varieties with the previous research results when potatoes were cultivated conventionally $(N 1)$ and analysed on DM [43], DM content in the tubers of Imanta variety are closely the same while in the tubers of the Lenora and Brasla varieties, DM content in this study year is much higher [43]. Tajner-Czopek et al from Poland has reported that DM content of the potato tubers of Blue Congo variety

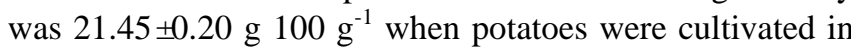
year 2009 and 2010 [47] and comparing to the results obtained in this research is a little bit higher.

Significant differences in DM content were found between varieties $(p<0.001)$, storage $(p<0.001)$ and cultivation type $(p<0.001)$. In regard to the cultivation type, significant differences in DM content were noticed between conventionally (N1) and conventionally (N2) cultivated potatoes and no significant differences $(p>0.05)$ were found in both ( $N 1$ and $N 2$ ) conventionally cultivated potatoes 
comparing to potatoes cultivated organically.

Changes in DM content determined for potatoes was significantly different at the time of harvesting and after storage, and this can be related to the increase in the transpiration rate of the tubers due to tuber life processes and sprouting [48], [49]. This increase in the evaporation process is due to high permeability of the epidermis of the sprouts and due to the increase in the evaporation surface [48]-[51]. Transpiration causes water loss, and as a consequence increases the content of all the components of the dry matter.

Potatoes (Solanum tuberosum L.) is considered a good source of antioxidants such us ascorbic acid, $\alpha$-tocopherol and polyphenolic compounds. In the research total phenolic content (TPC) in potatoes stored for the period of six months was higher than in potatoes just after harvesting and in average it has increased in organically cultivated potatoes per $16.9 \%$, conventionally $(N 1)-18.3 \%$ and $(N 2)-29.2 \%$ respectively.

In the analyzed potatoes before storage, the highest TPC was determined for the tubers of the Agrie dzeltenie variety when cultivated organically (i.e. $29.906 \pm 0.162 \mathrm{mg}$ GAE 100 $\mathrm{g}^{-1} \mathrm{FW}$ ) and after a period of storage - of the Blue Congo variety when cultivated conventionally $(N 2)$ (i.e. $53.334 \pm 0.199 \mathrm{mg}$ GAE $100 \mathrm{~g}^{-1} \mathrm{FW}$ ) Table III. Before a period of storage, in the yellow flesh potato tubers were higher amount of TPC comparing to tubers with violet flesh while vs. was after a period of storage.

Since in the research early, mid-early, mid-late and late varieties were used, potato maturity can be found to be different and during the post-harvesting stage some of the varieties can reach the maturity stage. It has been found that maturity stage can be one of the factors influencing TPC. Reyes et al. has observed that TPC in tubers decreased with tubers growth and maturity [52]. The TPC may be affected during the development of the flesh colour (purple, violet, yellow) of potato tubers [53], due to the environmental conditions, such as longer days and cooler temperatures or fertilization [52], [54], [55]. The effect of the cultivar and the differences between yellow and purple-fleshed cultivars in TPC has been found significant. The purple-fleshed cultivars contained on average $58.1 \%$ more total phenolics compared to the yellow-fleshed cultivars. In regard to the agronomic practise, it was suggested that application of synthetic fertilizers make the nitrogen available, which is utilized for growth but not allocated for the production of secondary metabolites such us phenols. Where as organic agriculture leads to an enhancement of natural defence substances such as phenolic compounds (Winter and Davis, 2006). In the current research, TPC has been found to be predominantly higher in organically cultivated potato tubers comparing to conventionally cultivated potato tubers while focusing on the amount of nitrogen used in each of conventionally cultivation practise $\left(N 1-60 \mathrm{~kg} \mathrm{ha}^{-1}\right.$ and $\left.N 2-120 \mathrm{~kg} \mathrm{ha}^{-1}\right)$, TPC was predominantly higher in potato tubers cultivated conventionally with doubled dose of $N-120 \mathrm{~kg} \mathrm{ha}^{-1}(N 2)$, but it varied per variety.

Like it was reported by Faller and Failho (2009), also in this particular research, significant differences were noticed in TPC when evaluating it within the varieties $(p<0.001)$ used in the research and within non-stored and stored potato tubers $(p<0.001)$ while no significant differences were noticed within the agricultural practise used $(p>0.05)$. In some studies have been found that storage generally increases TPC abut little changes or a decrease have also been reported [57]-[59].

The highest carotenoid content for non-stored potatoes was determined for the tubers of the Annuscha variety (i.e. $\left.0.400 \pm 0.007 \mathrm{mg} \quad 100 \mathrm{~g}^{-1} \mathrm{FW}\right)$ when potatoes were conventionally cultivated $(N 2)$ with the rate of $N$ fertilizer $120 \mathrm{~kg} \mathrm{ha}^{-1}$. The second highest carotenoid content was found in the same Annuscha variety when organically cultivated (i.e. $0.354 \pm 0.003 \mathrm{mg} 100 \mathrm{~g}^{-1} \mathrm{FW}$ ). Detailed information is shown in Table IV. Bonierbale et al has found that carotenoid content might vary in potatoes from 0.103 to

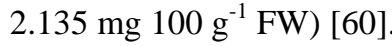

Carotenoid content per $100 \mathrm{~g}$ of tubers after a period of storage for some of the varieties was increased but for some it was decreased, but it does not show significant differences between non-stored and stored potatoes $(p>0.05)$ while between varieties differences were found to be significant $(p<0.001)$.

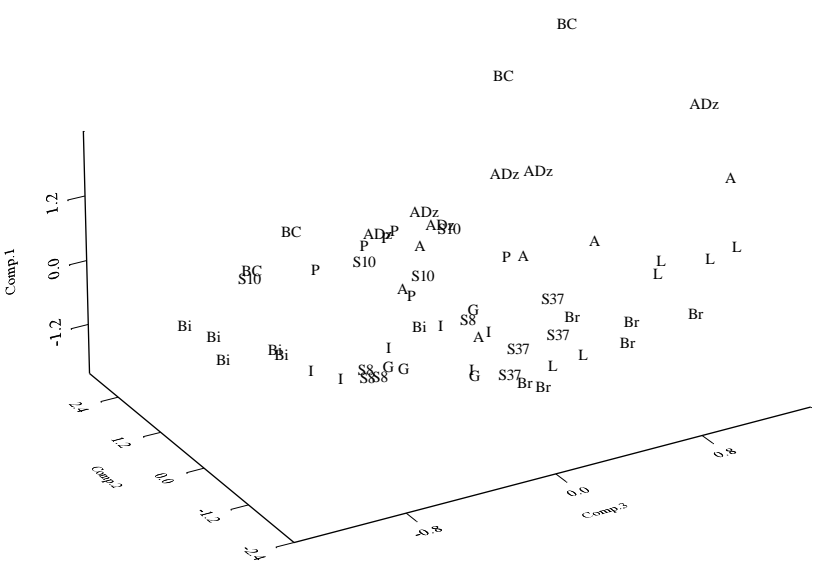

Fig. 1. Principle component analysis. Projection of the analyzed potato samples showing the influence of storage and cultivation type on carotenoids, TPC and DM in the space formed by the comp.1, comp.2 and comp.3. Abbreviations used in the figure: ADZ-Agrie dzeltenie, P-Prelma, I-Imanta, L-Lenora, Br-Brasla, Bi-Bionica, A-Annuscha, BC-Blue Congo, G-Gundega, S37-S04009-37, S10-S03135-10, S8-S99108-8

These differences might be influenced by several factors, for example variety and maturity stage of tubers [43]. It has been found that total carotenoid content is higher in immature tubers and it decreased with tuber maturity [61], [62]. In addition, Katikova et al. have found that the application of fertilizers does not bring any significant changes in carotenoids of potatoes while particular research show significant changes in the content of carotenoids between organically and conventionally $(N 1)$ grown potatoes $(p<0.05)$.

Dissimilarities between varieties, especially in case of wide ranges within one and the same variety, explain the importance of factors was taken into account (cultivation type and storage) and their affect on TPC, carotenoids and DM content.

In the research colour was analysed on potato tubers with white, yellow and violet flesh and relationship between colour and carotenoid and TPC was found (Table V).

In the analysis of the tubers' flesh colour, it has been found 
that there is a tendency having darker potato flesh with higher carotenoid content. The orange and yellow colour of the tuber flesh is due to zeaxanthin and lutein, respectively [24].

\section{CONCLUSION}

The changes in carotenoid content, total phenolic content (TPC) and dry matter (DM) content of potatoes vary significantly according to the type of cultivation practise, depending on the potato variety and the type of season (before or after storage). There are common tendencies in the changes of separate indices: in the case of cultivation practise (organically, conventionally (two different amounts of $N$ fertilizer were used: $N 1-60 \mathrm{~kg} / \mathrm{ha}$ and $N 2-120 \mathrm{~kg} / \mathrm{ha})$ ), significant differences were noticed in DM $(p<0.001)$ and carotenoid content $(p<0.05)$; between non-stored and stored potatoes - on DM $(p<0.001)$ and TPC $(p<0.001)$ while the variety was most significant factor in all cases - on DM, TPC and carotenoid content $(p<0.001)$.

Correlation between colour $\left(b^{*}\right)$ and carotenoid content was found from 0.53 to 0.74 in organically and conventionally ( $N 1$ and N2) cultivated potatoes; on colour $a^{*}$ was found the correlation in conventionally $(N 1)$ cultivated potatoes both on carotenoids and TPC while on $L^{*}$ - on carotenoid content in organically cultivated potatoes and on TPC in conventionally $(N 1)$ cultivated potatoes.

\section{ACKNOWLEDGMENT}

The authors acknowledge financial support from the following: project „Sustainable use of local agricultural resources for development of high nutritive value food products (Food)" within the National Research Programme "Sustainable use of local resources (earth, food, and transport) - new products and technologies (NatRes)" (2010.-2013.) and ERAF Project, Promotion of scientific activities of LLU", Contract Nr. 2010/0198/2DP/2.1.1.2.0/10/APIA/VIAA/020.

\section{REFERENCES}

[1] M. Friedman, "Chemistry, biochemistry, and dietary role of potato polyphenols. A review," Journal of Agricultural and Food Chemistry, vol. 45, pp. 1523-1540, 1997.

[2] R. Ezekiel, N. Singh, S. Sharma, and A. Kaur, "Beneficial phytochemicals in potato. A review," Food Research International, 2011.

[3] M. B. Katan and N. M. D. Roos, "Promises and problems of functional foods," Critical Reviews in Food Science and Nutrition, vol. 44, pp. 369-377, 2004

[4] C. H. Crisosto, G. M. Crisosto, and P. Metheney, "Consumer acceptance of 'Brooks' and 'Bing' cherries is mainly dependent on fruit SSC and visual skin color," Postharvest Biology and Technology, vol. 28, pp. $159-167,2003$.

[5] L.-C. Ou, M. R. Luo, A. Woodcock, and A. Wright, "A study of emotion and color preference. Part I. Color emotions for single colors," Color Research and Application, vol. 29, pp. 232-240, 2004.

[6] G. Jansen and W. Flamme, "Coloured potatoes (Solanum tuberosum L.) - anthocyanin content and tuber quality," Genetic Resources and Crop Evolution, vol. 53, pp. 1321-1331, 2006.

[7] J. Lachman, K. Hamouz, and M. Orsaká, "Red and purple coloured potatoes - a significant antioxidant source in human nutrition," Chemické Listy, vol. 99, pp. 474-482, 2005.

[8] F. B. Hu, "Plant-based foods and prevention of cardiovascular disease: An overview," American Journal of Clinical Nutrition, vol. 78, no. 3, pp. 544-551, 2003.

[9] G. Maiani, M. J. Caston, G. Catasta, E. Toti, I. G. Cambrodon, A. Bysted et al., "Carotenoids: Actual knowledge on food sources, intakes, stability and bioavailability and their protective role in humans," Molecular Nutrition and Food Research, vol. 53, no. 2, pp. 194-218, 2009.

[10] J. P. Spencer, "Flavonoids: Modulators of brain function?" British Journal of Nutrition, vol. 99, no. 1, pp. 60-77, 2008.

[11] D. M. Minich and J. S. Bland, "Dietary management of the metabolic syndrome beyond macronutrients," Nutrition Reviews, vol. 66, no. 8, pp. 429-444, 2008.

[12] D. C. Hunter, M. A. Skinner, and C. E. Lister, "Impact of phytochemicals on maintaining bone and joint health," Nutrition, vol. 24, no. 4, pp. 390-392, 2008.

[13] S. C. Thomasset, D. P. Berry, G. Garcea, T. Marczylo, W. P. Steward, and A. J. Gescher, "Dietary polyphenolic phytochemicals - Promising cancer chemopreventive agents in humans?" A Review of Their Clinical Properties, International Journal of Cancer, vol. 120, no. 3, pp. 451-458, 2007

[14] D. E. Stevenson and R. D. Hurst, "Polyphenolic phytochemicals - Just antioxidants or much more?" Cellular and Molecular Life Sciences, vol. 64, no. 22, pp. 2900-2916, 2007.

[15] J. A. Ross and C. M. Kasum, "Diertary flavonoids: Bioavailabiligy metabolic effects, and safegy," Annual Review on Nutrition, vol. 22, pp. 19-34, 2002.

[16] M. E. Camire, S. Kubow, and D. J. Donnelly, "Potatoes and human health," Critical Reviews in Food Science and Nutrition, vol. 49, no. 10, pp. 823-840, 2009.

[17] J. Lachman and K. Hamouz, "Red and purple coloured potatoes as a significant antioxidant source in human nutrition," Plant Soil Environment, a review, vol. 51, no. 11, pp. 477-482, 2005.

[18] C. R. Brown, "Antioxidants in potato," American Journal of Potato Research, vol. 82, pp. 163-172, 2005.

[19] R. Tsao, "Phytochemical profiles of potato and their roles in human health and wellness," Food, vol. 3, no. 1, pp. 125-135, 2009.

[20] D. Dellapenna and B. J. Pogson, "Vitamin synthesis in plants: Tocopherols and carotenoids," Annuual Review of Plant Biology, vol. 57, pp. 711-738, 2006.

[21] P. Fraser and P. Bramley, "The biosynthesis and nutritional uses of carotenoids," Progress in Lipid Research, vol. 43, pp. 228-265, 2004.

[22] H. Wang, M. G. Nair, G. M. Strasburg, Y. C. Chang, A. M. Booren, and J. I. Gray, „Antioxidant and anti-inflammatory activities of anthocyanins and their aglycon, cyaniding, from tart cherries," Journal of Natural Products, vol. 62, pp. 294-296, 1999.

[23] J. S. Tan, J. J. Wang, V. Flood, E. Rochtchina, W. Smith, and P. Mitchell, "Dietary antioxidants and the long-term incidence of age-related macular degeneration: The Blue Mountains Eye Study,' Ophthalmology, vol. 115, pp. 334-341, 2008.

[24] C. R. Brown, "Breeding for phytonutrient enhancement of potato," American Journal of Potato Research, vol. 85, pp. 298-307, 2008.

[25] G. Duthie, S. Duthie, and J. Kyle, "Plant polyphenols in cancer and heart disease: implications as nutritional antioxidants," Nutrition Research Review, vol. 13, pp. 79-106, 2000.

[26] P. Mattila and J. Hellstrom, "Phenolic acids in potatoes, vegetables, and some of their products," Journal of Food Composition and Analysis, vol. 20, pp. 152-160, 2006.

[27] C. Manach, A. Scalbert, C. Morand, C. Remesy, and L. Jimenez, "Polyphenols: Food sources and bioavailability," The American Journal of Clinical Nutrition, vol. 79, pp. 727-747, 2004.

[28] L. Bravo, "Polyphenols: Chemistry, dietary sources, metabolism and nutritional significance," Nutrition Reviews, vol. 56, pp. 317-333, 1998.

[29] M. S. Al-Saikhan, L. R. Howard, J. C. Miller, "Antioxidant activity and total phenolics in different genotypes of potato (Solanum tuberosum L.)," Journal of Food Science, vol. 60, pp. 341-343, 1995.

[30] O. K. Chun, D. O. Kim, N. Smith, D. Schroeder, J. T. Han, and C. Y. Lee, "Daily consumption of phenolics and total antioxidant capacity from fruit and vegetables in the American diet," Journal of the Science of Food and Agriculture, vol. 85, pp. 1715-1724, 2005.

[31] W. F. Talburt, S. Schwimmer, and H. K. Burr, "Structure and chemical composition of the potato tuber," In W. F. Talburt, \& O. Smith (Eds.), Potato Processing, New York: Van Nostrand Reinhold, pp. 11-46, 1987.

[32] Z. M. A. Kader, "Studies on retention of some water-soluble vitamins in potatoes and cow peas as affected by thermal processing and storage," Die Nahrung, vol. 34, no. 10, pp. 899-904, 1990.

[33] A. D. Dangour, S. K. Dodhia, A. Hayter, E. Allen, K. Lock, and R. Uauy, "Nutritional quality of organic foods: A systematic review," The American Journal of Clinical Nutrition, vol. 90, pp. 680-685, 2009.

[34] A. Moschella, F. Camin, F. Miselli, B. Parisi, G. Versini, P. Ranalli et al., "Markers of characterization of agricultural regime and 
geographical origin in potato," Agroindustria, vol. 4, no. 3, pp. 325-332, 2005

[35] A. Toledo and B. Burlingame, "Biodiversity and nutrition: a common path toward global food security and sustainable development," Journal of Food Composition and Analysis, vol. 19, no. 6-7, pp. 477-483, 2006.

[1] M. Clark, W. Horwath, C. Shennan, and K. Scow, "Changes in soil chemical properties resulting from organic and low-input farming practices," Agronomy Journal, vol. 90, no. 5, pp. 662-671, 1998

[36] B. Hansen, H. F. Alroe, and E. S. Kristensen, "Approaches to assess the environmental impact of organic farming with particular regard to Denmark," Agriculture, Ecosystems and Environment, vol. 83, pp. $11-26,2001$.

[37] A. D. V. Diepeningen, O. J. D. Vos, G. W. Korthals, and A. H. C. V. Bruggen, "Effects of organic versus conventional management on chemical and biological parameters in agricultural soils. Agriculture," Ecosystems and Environment, vol. 31, pp. 120-135, 2006

[38] Eurostat. (2010). Statistical Office of the European Communities, Organic area up by $21 \%$ in the EU between 2005 and 2008. [Online] Available:

http://epp.eurostat.ec.europa.eu/cache/ITY_PUBLIC/5-01032010-BP/ EN/5-01032010-BP-EN.PDF.

[39] P. Carillo, D. Cacace, S. D. Pascale, M. Rapacciuolo, and A. Fuggi, "Organic vs. traditional potato powder," Food Chemistry, vol. 133, pp. 1264-1273, 2012.

[40] K. Woese, D. Lange, C. Boess, and K. W. Bogl, "Acomparison of organically and conventionally grown foods-Results of a review of relevant literature," Journal of the Science of Food and Agriculture, vol. 74, pp. 281-293, 1997.

[41] D. Bourn and J. Prescott, "A comparison of the nutritional value, sensory qualities, and food safety of organically and conventionally produced foods," Critical Reviews in Food Science and Nutrition, vol. 42, pp. 1-34, 2002.

[42] I. Murniece, D. Karklina, R. Galoburda, D.Santare, I. Skrabule, and H. S. Costa, "Nutritional composition of freshly harvested and stored Latvian potato (Solanum tuberosum L.) varieties depending on traditional cooking methods," Journal of Food Composition and Analysis, vol. 24,pp. 699-710, 2011.

[43] ISO, International Organization for Standardization, ISO 6496-1999, Determination of moisture and other volatile matter content. 1999.

[44] А. И. Ермаков, "Методы биохимического исследования растений. Под ред," А.И.Ермакова, Ленинград, ВО «Агропромиздат», pp. 112-113, 1987.

[45] V. L. Singleton, R. Orthofer, R. M. L. Raventos, "Analysis of total phenols and other oxidation substrates and antioxidants by means of Folin-Ciocalteu reagent," Methods in Enzymology, vol. 29, pp. 152-178, 1999.

[46] A. T. Czopek, E. Rytel, A. Kita, A. Pęssa, and K. Hamouz, "The influence of thermal process of coloured potatoes on the content of glycoalkaloids in the potato products," Food Chemistry, vol. 133, no. 4, pp. 1117-1122, 2012.

[47] R. H. Booth and R. L. Shaw, "Principios de almacenamiento de la papa," C.I.P. Lima, Hemisferio Sur S.R.L., 1989.

[48] W. G. Burton, A. Va. Es, and K. J. Hartmans, "The physics and physiology of storage," in the Potato Crop Harris, P.M. (Ed.), Chapman and Hall, London, UK, 1992.

[49] R. R. Casañas, R. E. Rodríguez, and R. C. Díaz, "Effects of current storage conditions on nutrient retention in several varieties of potatoes from Tenerife," Food Chemistry, vol. 80, pp. 445-450, 2003.

[50] C. Gandarias and M. Lobo, "Conservación de la patata," Junta General de la Agrupación Nacional de la Patata, Madrid, 1975.

[51] L. F. Reyes, J. C. Miller, and L. C. Zevallos, "Environmental conditions influence the content and yield of anthocyanins and total phenolics in purple- and red-flesh potatoes during tuber development," American Journal of Potato Research, vol. 81, pp. 187-193, 2004.

[52] J. Lachman, K. Hamouz, M. Orsaká, V. Pivec, and P. Dvorák, "The influence of flesh colour and growing locality on polyphenolic content and antioxidant activity in potatoes," Scientia Horticulturae, vol. 117, pp. 109-114, 2005

[53] P. Kumar, S. K. Pandey, S. V. Singh, S. Rawal, and D. Kumar, "Effect of potassium fertilization on processing grade tuber yield and quality parameters in potato (Solanum tuberosum L.)," The Indian Journal of Agricultural Sciences, vol. 74, pp. 177-179, 2004.

[54] J. Hajšlová, V. Schulzová, P. Slanina, K. Janne, K. E. Hellenas, C. Andersson, "Quality of organically and conventionally grown potatoes: four-year study of micronutrients, metals, secondary metabolites, enzymic browning and organoleptic properties," Food Additives and Contaminants, vol. 22, pp. 514-534, 2005.
[55] C. K. Winter and S. F. Davis, "Organic foods," Journal of Food Science, vol. 71, pp. 117-124, 2006.

[56] R. Ezekiel and B. Singh, "Changes in contents of sugars, free amino acids and phenols in four varieties of potato tubers stored at five temperatures for 180 days," Journal of Food Science and Technology, vol. 44, pp. 471-477, 2007

[57] R. Ezekiel, V. Paul, B. Singh, A. Peshin, and G. S. Shekhawat, "Effect of low temperature, desprouting and gibberellic acid treatment on little tuber formation on potatoes during storage," Journal of Indian Potato Association, vol. 27, pp. 13-23, 2000.

[58] T. Blessington, M. N. Nzaramba, D. C. Scheuring, A. L. Hale, L. Reddivari, and J. C. Miller, "Cooking methods and storage treatments of potato: Effects on carotenoids, antioxidant activity, and phenolics," American Journal of Potato Research, vol. 87, pp. 479-491, 2010

[59] M. Bonierbale, W. Gruneberg, W. Amoros, G. Burgos, E. Salas, E. Porras, and T. M. Felde, "Total and individual carotenoid profiles in Solanum phureja cultivated potatoes: II. Development and application of near-infrared reflectance spectroscopy (NIRS) calibrations for germplasm characterization," Journal of Food Composition and Analysis, vol. 22, pp. 509-516, 2009.

[60] Z. Kotikova, A. Hejtmankova, J. Lachman, K. Hamouz, E. Trnkova, and P. Dvorak, "Effect of selected factors on total carotenoid content in potato tubers (Solanum tuberosum L.)," Plant Soil Environment, vol. 53, pp. 355-360, 2007.

[61] W. L. Morris, L. Ducreux, D. W. Griffiths, D. Stewart, H. V. Davies, and M. A. Taylor, "Carotenogenesis during tuber development and storage in potato," Journal of Experimental Botany, vol. 55, pp. 975-982, 2004

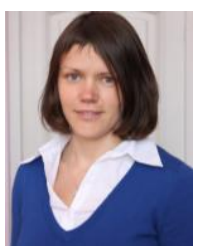

Irisa Murniece was born in Latvia, Cesis at 1980. She has obtained doctoral degree in the field of Food Science at Latvia University of Agriculture (2010) and Master degree - Food Science and Nutrition at Gent University (Belgium) (2007). Now she is working as a leader researcher at the Department of Food Technology. Her field of the research is potatoes, vegetables and its quality before and after processing as well as analyses of the physical properties of the food. Her interest is human nutrition. She has about 40 published papers and participated in ten different projects both in national and European level.

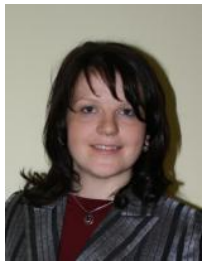

Zanda Kruma is leader researcher at the Latvia University of Agriculture, Faculty of Food Technology, who was born in Latvia, Aizpute in 1980. In 2008 she defended $\mathrm{PhD}$ thesis and obtained doctoral degree in food science. Main topics of research: biologically active substances in foodstuffs, food aroma analysis. She has 40 scientific publications and participated in 6 different projects.

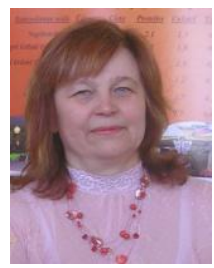

Ilze Skrabule is a eading researcher, potato breeder at State Priekuli Plant Breeding Institute. She was born in Latvia, Riga at 1959. She has defended her Dr. in agricultural sciences in Latvia University of Agriculture at 2003. Doctoral thesis was "The evaluation of traits suitable for processing requirements in potato initial breeding material". Scientific directions are breeding for organic farming and important for human health compound in tubers. She has about 35 scientific publications. At present leading researcher in Project "Development, improvement and implementation of environmentally friendly and sustainable crop breeding technologies", Contract Nr.2009/0218/1dp/1.1.1.2.0/09/APIA/VIAA/099.

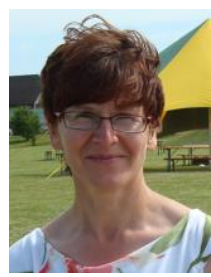

Aija Vaivode is a scientific assistant, specialized in crop management at State Priekuli Plant Breeding Institute with the experience more than 20 years. She was born in Latvia, 1959. 